\title{
In Vitro Pollen Germination of Eichbornia crassipes (Mart.) Solms: An Insight into its Preferred Mode of Clonal Reproduction
}

\author{
Somnath BHOWMIK*, Badal Kumar DATTA \\ Tripura University, Department of Botany, Plant Taxonomy and Biodiversity Laboratory, 799022 Suryamaninagar, India; \\ sombhowmik@gmail.com (*correspondingauthor)
}

\begin{abstract}
Eichhornia crassipes (Mart.) Solms is an aquatic invasive weed throughout the tropical and subtropical regions of the world. The plant rarely produces any fruit under natural condition In order to understand the causes of failure of seed set in this plant various aspect of pollen biology were studied. Pollen fertility and pollen viability was assessed using Muntzing's mixture and in acetic orcein and TTZ, while pollen germination was assessed with different concentrations of sucrose supplemented with boric acid and Ca and $\mathrm{Mg}$ salts. The aim of present study was to find out the cause of sexual incompatibility of Eichhornia crassipes (Mart.) Solms. In spite of high pollen fertility, pollen viability and pollen germination the species show hardly any fruit set under natural condition. The abnormal pollen germination like curling of pollen tubes, shrinkage of pollen tube tips and bending of pollen tube might be reasons of sexual incompatibility of this species. It is observed that the taxa required comparatively low sucrose concentration (5\%) for their optimal in vitro pollen germination (54.08\%). Boric acid to certain extent also influences the in vitro pollen germination $(56.2 \%)$. In the present investigation the nature of substrate in association with the effect of Boric acid, $\mathrm{CaCO}_{3}, \mathrm{MgSO}_{4}$ on the in vitro pollen germination of Eichhornia crassipes is also worked out. However the tested salts show no significant effect on pollen germination in the present study.
\end{abstract}

Keywords: clonal reproduction, germination success, incompatible pollen, pollen viability

\section{Introduction}

Eichhornia crassipes (Mart.) Solms the water hyacinth is an extremely aggressive aquatic weed throughout tropical and subtropical regions of the world. Its profile vegetative reproduction, the apparent key to its success as a weed has received attention from many workers, whereas its floral biology has received less attention. Controlled pollination studies on clones of E. crassipes demonstrated that a high degree of seed fertility accompanies the well documented capacity for vigorous clonal propagation (Barrett, 1977a, 1977b, 1979, 1980; Mulcahy, 1975). This suggest the environmental factors play a major role in limiting sexual reproduction under field condition. Although several workers have suggested environmental factors which might limit sexual reproduction in E. crassipes, eg scarcity of pollinators (Penfound and Earle, 1948), unfavourable climatic conditions preventing seed formation (Agharkar and Banarjii, 1930; Parija, 1934). The successful sexual reproduction on the other hand depends on formation of viable male gametophytes with sperm cells, female gametophytes with a functional egg cell and, after double fertilization, embryos and seeds able to germinate. Usually sexual reproduction is combined with vegetative propagation, allowing clones to be produced when sexual reproduction fails; in this way the genetic structure of the population is influenced by the two modes of reproduction. The switch to asexual reproduction itself is usually a selective disadvantage in adverse conditions but is sometimes maintained (Dechamps et al., 2007; Deng et al., 2007). Many authors have found various kinds of developmental disturbances and degenerative processes in anthers and ovules of pioneer colonizing plants, resulting in a high percentage of aborted ovules and anthers (Bliskup and Izmailow, 2004; Izmailow, 2000; Izmailow and Bliskup, 2003; Koscinska-Pajak, 2000; Malayeri et al., 2005; Micieta and Murin, 1996; Ostrolucka et al., 1995; Ostrolucka, 1989). Pollen germination and the growth of pollen tubes are, in principle, necessary for fertilization and seed formation in flowering plants. A good fruit set and high crop yield depend on healthy pollen grains of respective plants (Bhowmik and Datta, 2011). Studies on in vitro pollen germination and pollen tube growth are very useful for explaining the lack of fertility (Pfahler et al., 1997). Various methods are applied to study the pollen geminability in horticultural crops. The viability of pollen is defined as "having the capacity to live, grow, germinate, or develop". But viable pollen may not actually germinate in vitro or in vivo if the conditions are not suitable (Beyhan and Serdar, 2008). In the aquatic angiosperms is rather difficult for the great majority of species due to limited flowering opportunity. Clonal reproduction, therefore, plays an essential role in their recruitment (Grace, 1993). Moreover, several forms of clonal offspring, such as, winter buds, and shoot fragment are highly economical in aquatic environment, reducing the selective value of sexual reproduction 
66

(Grace, 1993; Les and Philbrick, 1993). In the present investigation, an attempt has been made to find out the nature of the substrate along with the effect of Boric acid, $\mathrm{CaCO}_{3}, \mathrm{MgSO}_{4}$ on the in vitro pollen germination of $E$. crassipes growing on wild condition in different wetlands of Tripura.

\section{Materials and methods}

In vitro pollen germination study was carried out on the fresh flower buds of Eichhornia crassipes (Mart.) Sol$\mathrm{ms}$. The flower bud were collected from lakes in the morning $(8.00 \mathrm{am})$ before anthesis and transferred to polythene bags. To find out the nature of the substrate of the germinating media for the studied taxa tap water, distilled water and seven different concentrations of sucrose solution $(1 \%, 2 \%, 5 \%, 10 \%, 15 \%, 20 \%$ and $25 \%)$ were tested. In addition to that the effect of different chemical substances like Boric acid, $\mathrm{CaCO}_{3}, \mathrm{MgSO}_{4}$ were also studied on both the germination as well pollen tube development in combination with sucrose. Blotting paper was placed into each sterile petri dish, and 2 slides were put on the blotting paper. Then $50 \mu \mathrm{l}$ nutrient medium were dropped onto the grove slides. Further, pollen taken from flower anthers with a pin was carefully spread on this solution. The control treatment was solely $50 \mu \mathrm{l}$ distilled water. The experiment was performed with two replications. Subsequently, the petri lids were closed and incubated at $37^{\circ} \mathrm{C}$ for 1 hour. Finally, the slides in the incubated petri dishes were examined and counted under a microscope in terms of germinated and ungerminated pollen in 4 different observation sections to determine the germination ratio of pollen in percentages. As for the average length of pollen tubes, the lengths of 10 germinated pollen tubes randomly chosen from each of the 4 different observation sections were measured and the averages were recorded in $\mu \mathrm{m}$. The pollen viability was assessed using $1 \% \mathrm{TTZ}$ in $1 \%$ sucrose solution, whereas the pollen fertility was assed using the Muntzing's mixture and in acetic orcein.

\section{Results and discussion}

All the dyes used in this experiment for Eichhornia crassipes (Mart.) Solms showed good colour to differentiate between fertile and sterile pollens viz., Muntzing's mixture $(89.36 \pm 12.55)$ (Plate 1$)$ and acetic orcein $(67.22 \pm 7.50)$ (Plate 2$)$. The result indicated highly significant differences (calculated t value: $0.442 ; \mathrm{Pd} 0.01$ level) in pollen viability associated with the dyes which are used for to study the pollen fertility. Nyine and Pillay (2007) also found similar results in their experiments, emphasizing that pollen grain viability assessment through the staining method seem to express the germination potential, but not its occurrence. It may be explained by the fact that this technique overestimates the percentage of pollen tubes formed.

In the TTZ test the percentage of viable pollen is $64.23 \pm 6.28$ (Plate 3 ). Pollen viability is considered as an important parameter of pollen quality (Dafini and Frirmage, 2000). Pollen size and viability are good markers of the course of microsporogenesis. Normal meiosis produces pollen grains regular in size and highly viable, and disturbed meiosis reduces pollen viability and causesvari-

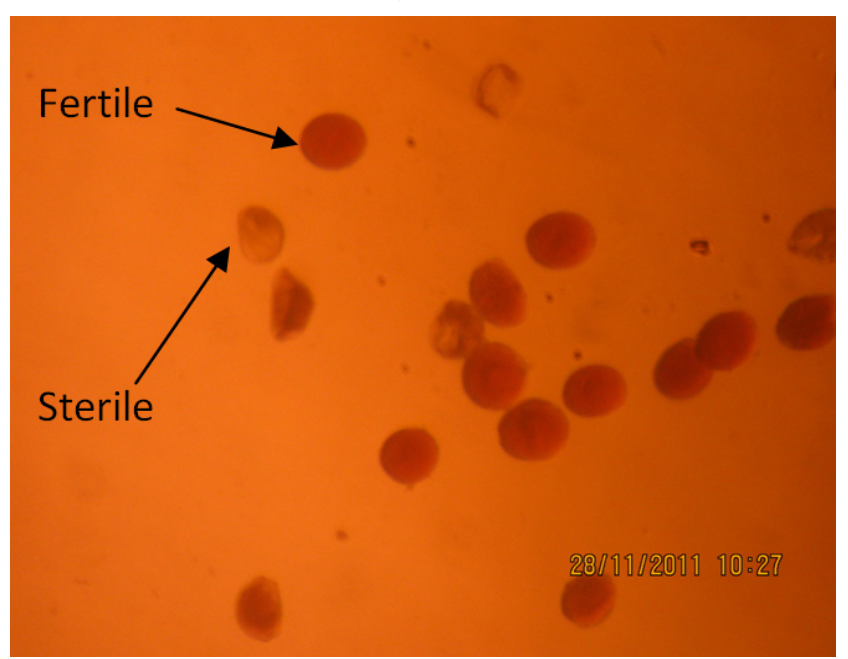

Plate 1. Pollen fertility using Muntzing's mixture

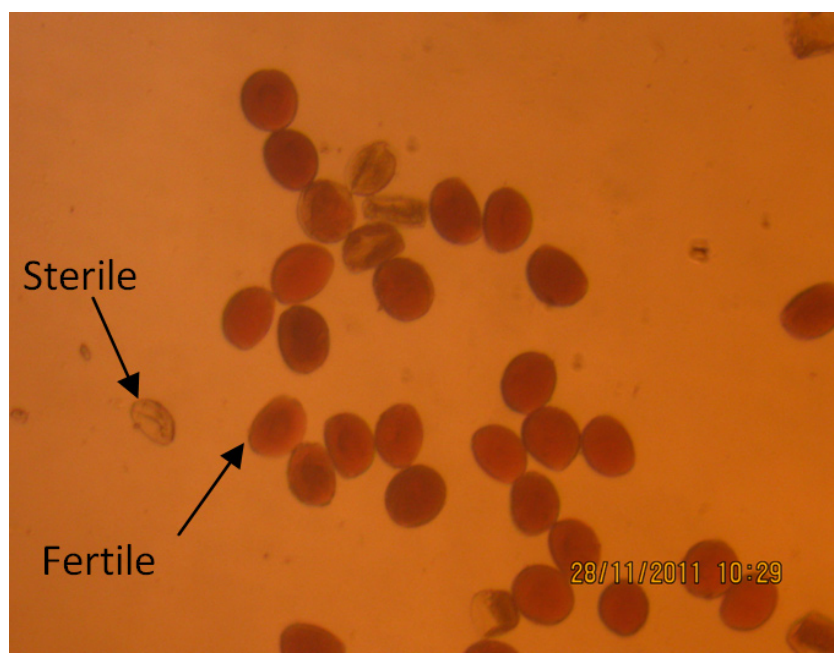

Plate 2. Pollen fertility using acetic-orcein mixture

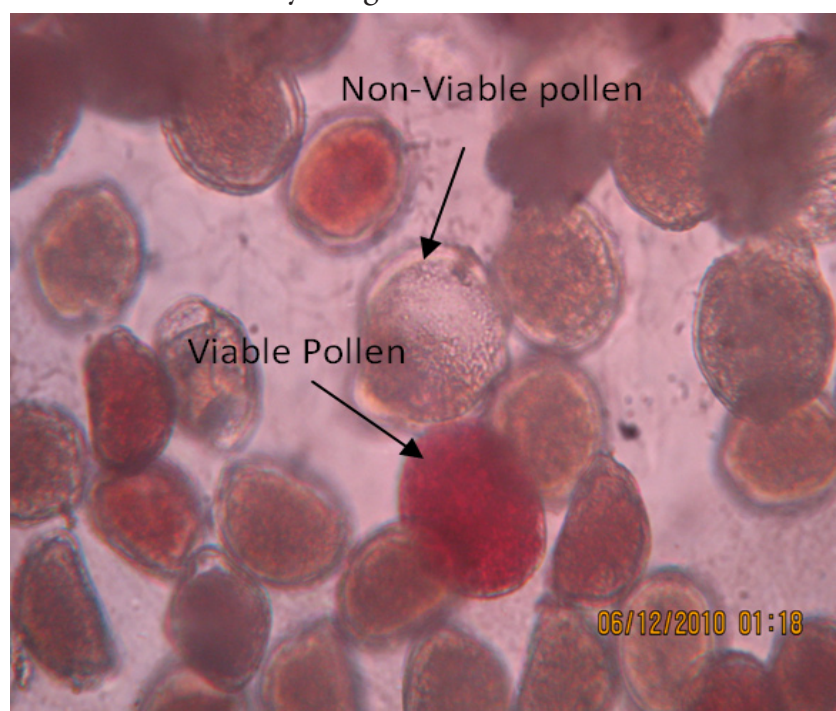

Plate 3. Viability test using $1 \%$ TTZ 
Tab. 1. Effect of sucrose solution in pollen germination of Eichhornia crassipes Mart. Solms

\begin{tabular}{|c|c|c|c|c|}
\hline \multirow[b]{3}{*}{ Concentration } & \multicolumn{4}{|c|}{ Eichhornia crassipes Mart. Solms } \\
\hline & \multicolumn{2}{|c|}{ Pollen germination $(\%)$} & \multirow[b]{2}{*}{$\begin{array}{c}\text { Total } \\
\text { germination } \\
(\%)\end{array}$} & \multirow[b]{2}{*}{$\begin{array}{r}\text { Tube } \\
\text { length } \\
(\mu \mathrm{m})\end{array}$} \\
\hline & $\begin{array}{c}\text { Normal } \\
\text { pollen } \\
\text { germination } \\
(\%)\end{array}$ & $\begin{array}{l}\text { Abnormal } \\
\text { pollen } \\
\text { germination } \\
(\%)\end{array}$ & & \\
\hline $1 \%$ & 10.84 & 21.43 & 32.27 & 172 \\
\hline $2 \%$ & 12.29 & 31.78 & 44.07 & 189 \\
\hline $5 \%$ & 14.96 & 39.12 & 54.08 & 280 \\
\hline $10 \%$ & 15.19 & 35.59 & 51.78 & 241 \\
\hline $15 \%$ & 4.50 & 10.69 & 15.19 & 147 \\
\hline $20 \%$ & 1.22 & 9.25 & 10.47 & 128 \\
\hline
\end{tabular}

ability of pollen grain size (very small and giant pollen are formed in addition to those normal in size); the latter can result from inbreeding depression, autopolyploidy, segmental allopolyploidy, hybridization, mutations, and also environmental effects (Stace, 1991). Besides pollen diameter measurement (Kelly et al., 2002) the quickest and simplest methods of assessing viability rely on different tests. These results tell us that the term "pollen viability" should be used carefully and rather replaced by the more limited term "pollen stainability," as it depends strictly on the staining assay. A number of authors have discussed the terms used to describe the viability of pollen grains and their ability to germinate and fertilize ovules, and have recommended different terms such as pollen sterility, stainability, viability, geminability, stigmatic geminability, fertilization ability, pollen quality (Dafni and Firmage, 2000; Klein, 2000). Stainable pollen grains may vary in size and thus be cytologically unbalanced and not viable. Pollen stainability rarely corresponds to pollen germination, which is the best index of pollen viability. In vitro germination, the success of which depends on medium composition

Regarding the effect of sucrose on in vitro pollen germination of Eichhornia crassipes, it is observed that the taxa required comparatively low sucrose concentration $(5 \%)$ for their optimal germination and Boric acid to certain extent also influence the percentage of pollen germination (Tab. 1 and 2). 5\% concentration of sucrose produces $54.08 \%$ pollen germination. But the best result was obtained from sucrose (5\%) with boric acid (100 ppm) combination and it was 56.2\% (Plate 4 and 5, Fig. 1).

Fertilization in flowering plants requires remarkable cellular co-ordination to carry sperm cells to the ovules through stylar tissues. The study of factors that control the reproductive process in higher plants necessitates a thorough knowledge of the pollen-pistil interactions. In vitro pollen germination method is rapid, reasonably simple and the most commonly used for assessing pollen viability. Since half of the pollen grains are viable in E. crassipes, pollen sterility cannot be attributed as reason for lack of seedset. In many species in vitro pollen germination showed positive correlation with fruit and seed-set (Jassen and
Tab. 2. Effect of boric acid and sucrose solution in pollen germination of Eichhornia crassipes Mart. Solms

\begin{tabular}{ccccc}
\hline & \multicolumn{3}{c}{ Eichhornia crassipes Mart. Solms } \\
\cline { 2 - 4 } Concentration & $\begin{array}{c}\text { Pollen germination }(\%) \\
\text { Normal } \\
\text { pollen } \\
\text { germination } \\
(\%)\end{array}$ & $\begin{array}{c}\text { Abnormal } \\
\text { pollen } \\
\text { germination } \\
(\%)\end{array}$ & $\begin{array}{c}\text { Total } \\
\text { germination } \\
(\%)\end{array}$ & $\begin{array}{c}\text { Tube } \\
\text { length } \\
(\mu \mathrm{m})\end{array}$ \\
\hline $100 \mathrm{ppm}+1 \%$ & 10.54 & 28.74 & 39.28 & 165 \\
\hline $100 \mathrm{ppm}+2 \%$ & 12.28 & 31.79 & 44.07 & 192 \\
$100 \mathrm{ppm}+5 \%$ & 22.00 & 34.2 & 56.2 & 287 \\
$100 \mathrm{ppm}+10 \%$ & 12.47 & 21.08 & 33.55 & 209 \\
$100 \mathrm{ppm}+15 \%$ & 2.11 & 10.65 & 12.76 & 157 \\
\hline $100 \mathrm{ppm}+20 \%$ & - & - & - & - \\
\hline
\end{tabular}

Hermsen, 1976). Such a correlation is not found in the case of E. crassipes (Banarjii and Gangulee, 1937). In the present study, the pollen tube showed various abnormalities e.g. curling of pollen tubes, buldging of tips and bending of pollen tube (Plate 6, 7,8 and 9) which ultimately inhibit the process of fertilization. The high proportion of various kind of abnormalities (39.12\% which accounts $72.33 \%$ of total pollen germination) clearly indicates that incompatible interaction takes place on the surface of the stigma where pollen tube growth is inhibited.

In general, the pollen tubes develop and deposit a considerable amount of callose along their wall during elongation, which is a pre-programmed step in the development of pollen tubes (Shivanna and Johri, 1985). In the germinating pollen grains of angiosperms, callose plugs are formed in the pollen tube as it grows. According to Laitiainen et al. (2002) callose plug formation helps to maintain a constant amount of cytoplasm containing the germ units in the pollen tube tip region without division of the tube cell, although it has been indicated that callose plug synthesis is not dependent on the movement of germ units into the tube. The formation and function of callose plug have been studied by Kobayashi et al. (2001) and Laitiainen et al. (2002). Although callose was originally believed to play a role in prevention of pollen tube penetration into the stigmatic papilla, recent evidence indicated that callose is unlikely to play an essential part of self recognition and rejection in some taxa (Franklin et al., 1995; Singh and Paolillo, 1990; Sulaman et al., 1997). In lily, it has been reported that the plug intervals of compatible pollen are more regular than those of incompatible pollen (Hasegawa et al., 2000). Quite often, callose is synthesized in the cell as a response to some stress conditions. According to Vishnyakova (1991), strong anomalous callose occlusions occur in pollen grains and pollen tubes as a result of their incompatible interactions with the pistil. Such non-programmed callose occlusions, as a rule, are linked with metabolic changes. Hence $E$. crassipes, there was an incompatible interaction between pollen tube and components on the surface of the stigma after self pollination which may cause metabolic changes. Probably this 
68

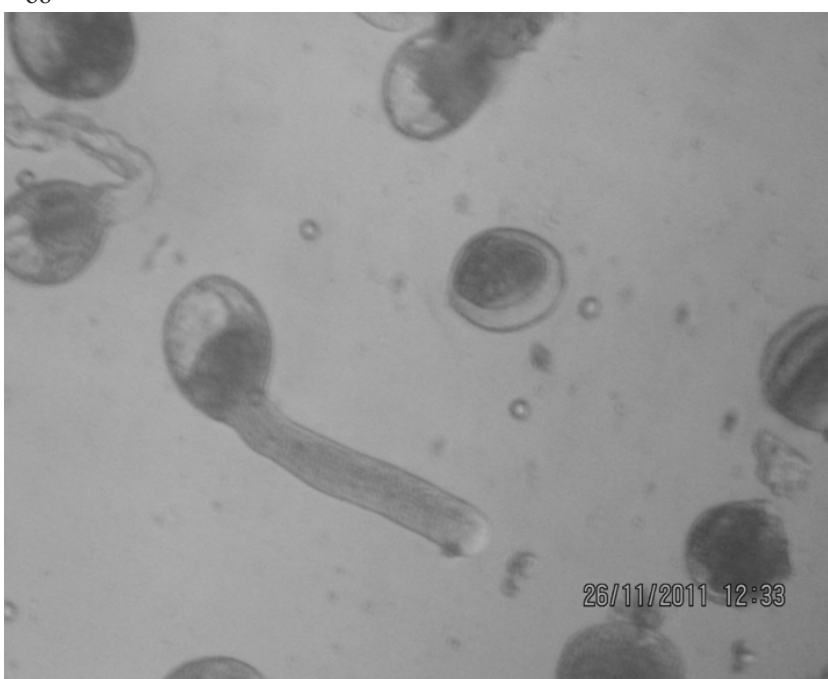

Plate 4. Normal pollen germination

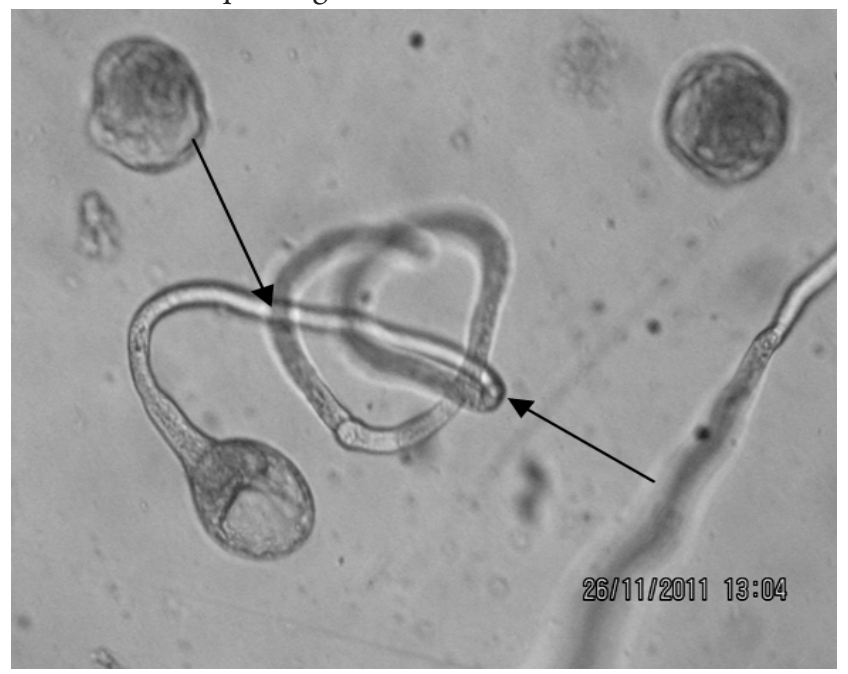

Plate 6. Abnormal coiling of pollen tube

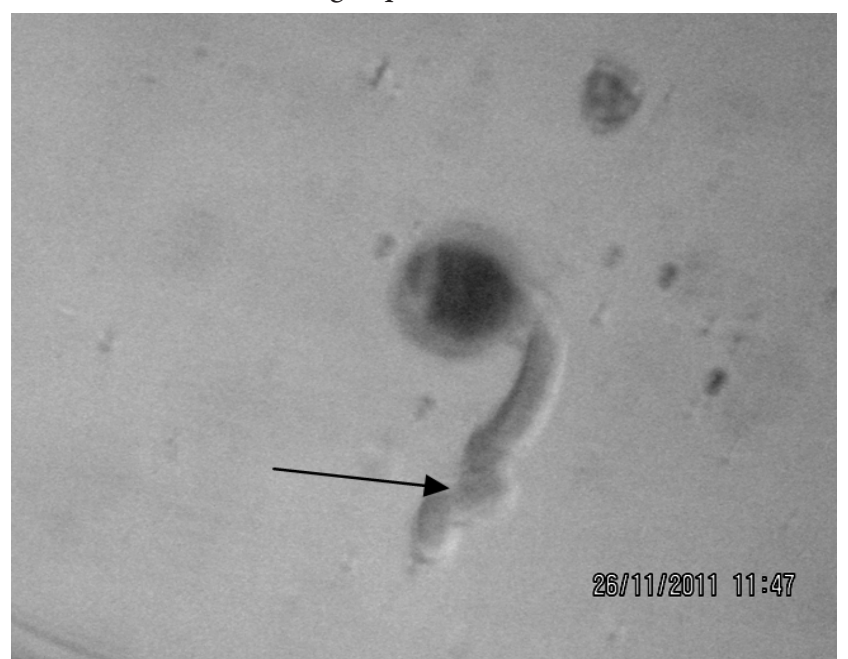

Plate 8. Abnormal shrinkage at the tip of pollen

leads to pollen tube growth inhibition and lack of seed-set in E. crassipes.

As a rule pollen grains do not contain chlorophyll, therefore, dependent on external sources for the survival of essential nutrients. Sucrose is the best carbohydrate source

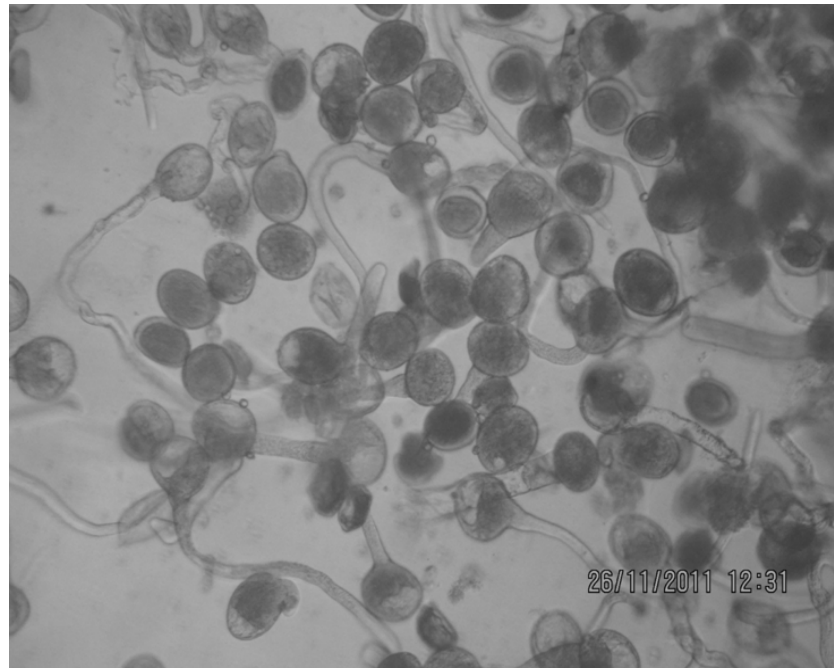

Plate 5. Normal and abnormal pollen germination

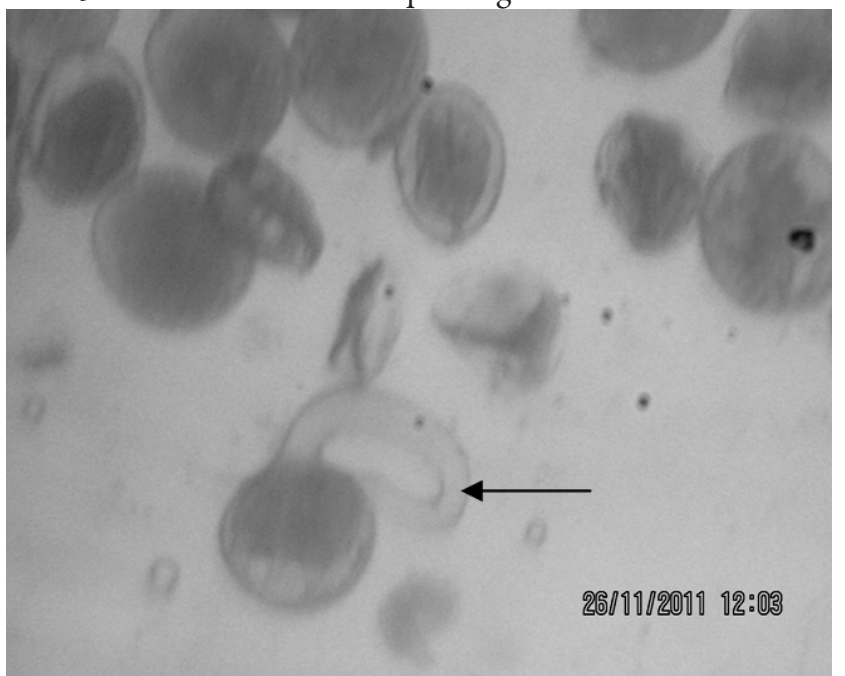

Plate 7. Abnormal bending of pollen tube

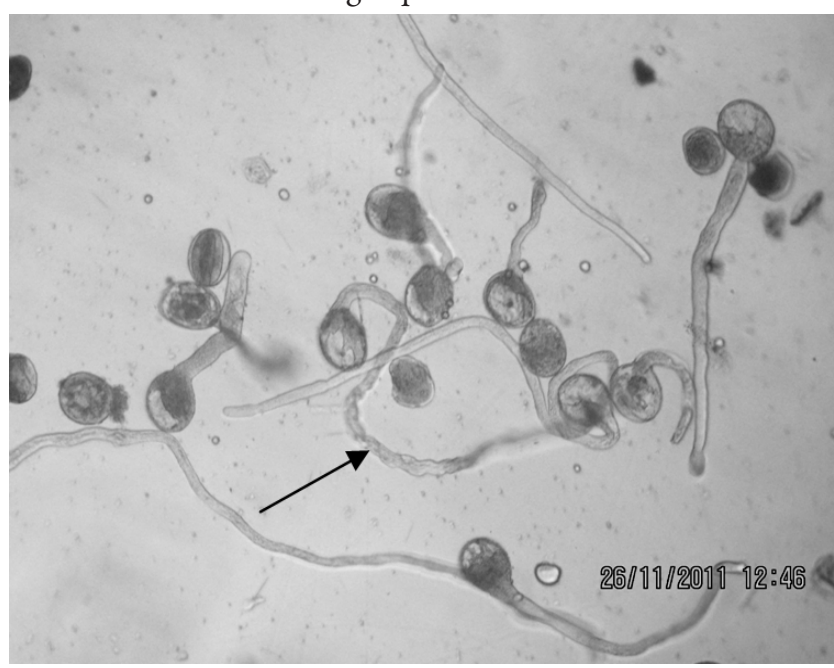

Plate 9. Abnormal shrinkage at the middle of pollen tube

for pollen germination, having its function in maintaining osmotic pressure of the medium and acting as a substrate for pollen metabolism (Johri and Vasil, 1961). The optimum concentration of sucrose uptake varies from species to species, even variety to variety (Bhattacharya and 

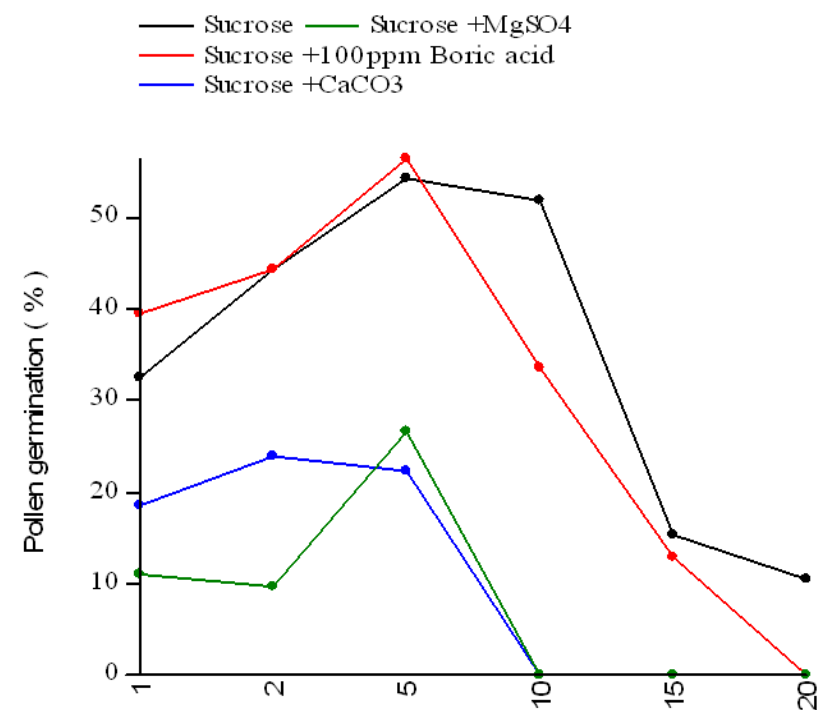

Sucrose concentration (\%)

Fig. 1. Graph showing effect of different concentration of media on pollen germination

Tab. 3. Effect of $\mathrm{CaCO}_{3}$ and sucrose solution in pollen germination of Eichhornia crassipes Mart. Solms

\begin{tabular}{ccccc}
\hline & \multicolumn{3}{c}{ Eichhornia crassipes Mart. Solms } \\
\cline { 2 - 4 } Concentration & \multicolumn{2}{c}{ Pollen germination (\%) } & Normal \\
\cline { 2 - 4 } & $\begin{array}{c}\text { Abnormal } \\
\text { pollen } \\
\text { pollen } \\
(\%)\end{array}$ & $\begin{array}{c}\text { Total } \\
\text { germination } \\
(\%)\end{array}$ & $\begin{array}{c}\text { Tube } \\
\text { length } \\
(\mu \mathrm{m})\end{array}$ \\
\hline $100 \mathrm{ppm}+1 \%$ & - & 18.36 & 18.36 & 135 \\
\hline $100 \mathrm{ppm}+2 \%$ & 10.95 & 12.92 & 23.87 & 187 \\
$100 \mathrm{ppm}+5 \%$ & - & 22.14 & $22.14^{* *}$ & 141 \\
$100 \mathrm{ppm}+10 \%$ & - & - & - & - \\
$100 \mathrm{ppm}+15 \%$ & - & - & - & - \\
$100 \mathrm{ppm}+20 \%$ & - & - & - & - \\
\hline
\end{tabular}

Calculated t value: $7.29 ;{ }^{* *}$ Significant at Pd" 0.01

Mandal, 2000). The investigated taxa show decreased rate of pollen germination while elevating the sucrose concentration. The rate of germination decreased in higher concentration, which seems to be inhibitory effect for pollen tube growth (Bhowmik and Datta, 2011). The higher concentration of sucrose is seems to be detrimental in pollen germination (Montaner et al., 2003). According to SariGorla and Frova (1997) inadequate high sugar concentrations reduce pollen germination and viability.

The importance of boron for pollen germination and tube growth was unknown until Dickinson (1978). Dickinson reported that boron binds in a reversible manner to growth related sites in pollen tube. Boron is a stimulatory agent for pollen germination and tube elongation. It is involved in the translocation and metabolism of sucrose. Stanley and Linskens (1964) indicated that the boron was involved in the production in pectin synthesis and thus was indirectly involved in the production of pollen tube mem-
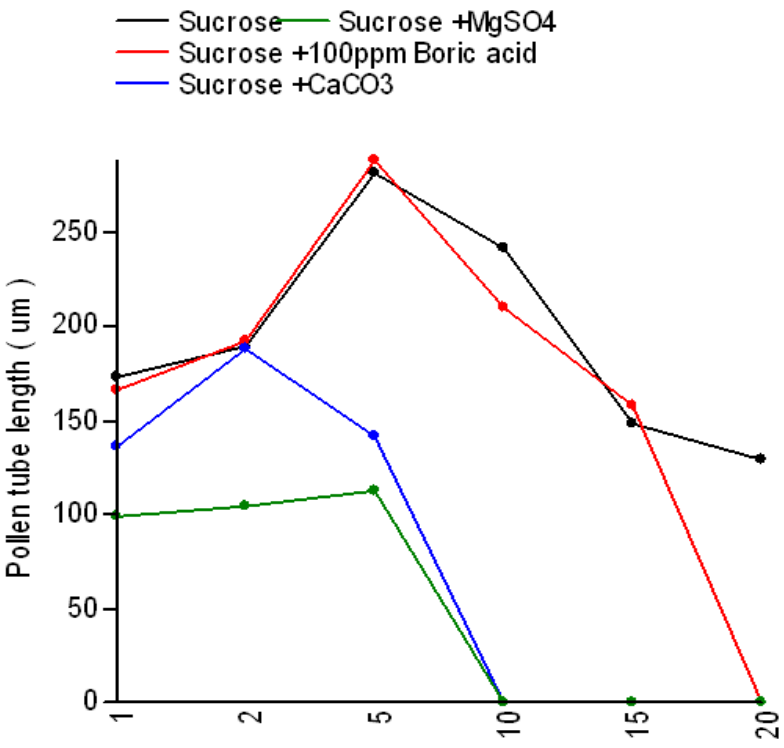

Sucrose concentration (\%)

Fig. 2. Graph showing effect of media on pollen tube length after anthesis on different concentration of media

Tab. 4. Effect of $\mathrm{MgSO}_{4}$ and sucrose solution in pollen germination of Eichhornia crassipes Mart. Solms

\begin{tabular}{|c|c|c|c|c|}
\hline \multirow[b]{3}{*}{ Concentration } & \multicolumn{4}{|c|}{ Eichhornia crassipes Mart. Solms } \\
\hline & \multicolumn{2}{|c|}{ Pollen germination (\%) } & \multirow[b]{2}{*}{$\begin{array}{c}\text { Total } \\
\text { germination } \\
(\%)\end{array}$} & \multirow[b]{2}{*}{$\begin{array}{l}\text { Tube } \\
\text { length } \\
(\mu \mathrm{m})\end{array}$} \\
\hline & $\begin{array}{c}\text { Normal } \\
\text { pollen } \\
\text { germination } \\
(\%)\end{array}$ & $\begin{array}{c}\text { Abnormal } \\
\text { pollen } \\
\text { germination } \\
(\%)\end{array}$ & & \\
\hline $100 \mathrm{ppm}+1 \%$ & - & 10.89 & 10.89 & 98 \\
\hline $100 \mathrm{ppm}+2 \%$ & - & 9.56 & 9.56 & 104 \\
\hline $100 \mathrm{ppm}+5 \%$ & 7.28 & 19.14 & $26.42^{* *}$ & 112 \\
\hline $100 \mathrm{ppm}+10 \%$ & - & - & - & - \\
\hline $100 \mathrm{ppm}+15 \%$ & - & - & - & - \\
\hline $100 \mathrm{ppm}+20 \%$ & - & - & - & - \\
\hline
\end{tabular}

brane. In the present study the sugar-borate complex to a certain extent can accelerate the pollen germination rate. In $E$. crassipes, the germination percentage was $56.20 \%$ in $100 \mathrm{ppm}$ boric acid with 5\% sucrose solution and maximum tube length was $287 \mu \mathrm{m}$ (Fig. 2). The concentration of boron is not critical on pollen germination (Montaner et al., 2003). The formation of protrusions through germ pores is independent of boric acid supply, but tube growth depends upon the presence of boric acid. Gauch and Duggar (1953) observed that, "Boron combines with sugar to form a sugar-borate complex (ionizable state) which is translocated with greater facility than the non borate sugar molecules (non ionized state). Different workers supported the fact that sucrose along with boric acid has the enhancing effects on both the germination and pollen tube development (Malik, 1977; Mandal et al., 1982; Nyggard, 1977; Pal et al., 1989; Ramanna, 1975). Calcium and magnesium salts were also tested for germination and 
70

tube growth of the studied taxa. Among the investigated taxa tested salts has no significant role in germination and tube growth $\left(\mathrm{CaCO}_{3}\right.$ : calculated $t$ value-7.29, $\mathrm{Pd} 0.01$ level; $\mathrm{MaSO}_{4}$ : calculated t value-7.66, Pd 0.01 level; Tab. 3 and 4). It can be predicted that the endogenous $\mathrm{Ca}$ and $\mathrm{Mg}$ level in the aquatic plants might be sufficient for pollen germination. Picton and Steer (1982) was confirmed that concentration of calcium above a specific level inhibited pollen germination. Bilderback (1981) reported that the higher concentration of $\mathrm{Ca}$ is inhibitory effect on pollen germination. Regarding the effect of $\mathrm{Ca}$ on pollen tube growth, it was pointed that calcium is concerned with the crowding effect of pollen grains. The crowding effect or population effect were found in the pollen of many taxa (Shivanna and Johri, 1989). Shivanna and Johri (1985) however, reported that the activities of specific membrane components are related to the presence of boron and calcium ions.

Germination success may depend on the humidity to which the pollen grains were exposed prior to the germination test and on the pollen age (Dafni et al., 2005). The differences in pollen germination among species may be due to genotypic variations and different environmental conditions during growth (Beyhan and Serdar, 2008). It is reported that germination success in sucrose medium might depend on the humidity at which the pollen grain was exposed prior to the germination test and on the pollen age (Heslop-Harrison, 1987). Nyine and Pillay (2007) stated that the genotype, medium and incubation time accounts for $65 \%$ variability on pollen germination potential. The remaining 35\% may be accounted for by other factors such as humidity, temperature, photo conditions and pollen harvesting times (Wang et al., 2005)

Hence, it could be concluded that in E. crassipes, there was an incompatible interaction between pollen tube and components on the surface of stigma due abnormal pollen germination. This leads to pollen tube growth inhibition and lack of seed set in this plant.

\section{Acknowledgements}

The first author is thankful Tripura University, India, for providing RET Fellowship in order to carry out the research work.

\section{References}

Agharkar SP, Banarjii I (1930). Studies in the pollination and seed formation of water hyacinth (Eichhornia speciosa Kunth.). Agric J India 25:286-296.

Banarjii I, Gangulee HC (1937). Spermatogenesis in Eichornia crassipes Solm. J Ind Bot Soc 16:289-296.

Barrett SCH (1977a). Breeding systems in Eichhornia and Pontederia, Tristylous genera of the Pontederiaceae. University of California, Berkeley, Ph.D Thesis.

Barrett SCH (1977b). Tristylous in Eichhornia crassipes (Mart.)
Solm (Water Hyacinth). Biotropica 9:230-238.

Barrett SCH (1979). The evolutionary breakdown of tristyly in Eichhornia crassipes (Mart.) Solm (Water Hyacinth). Evolution 33:499-510.

Barrett SCH (1980). Sexual reproduction in Eichhornia crassipes I. Fertility of clones from diverse regions. J Appl Ecol 17:101-112.

Beyhan N, Serdar U (2008). Assessment of pollen viability and geminability in some European chestnut genotypes (Castanea sativa L.). Hort Sci 35(4):171-178.

Bhattacharya A, Mandal S (2000). Pollination biology in Bombax ceiba Linn. Current Sci 79(12):1706-1712.

Bhowmik S, Datta BK (2011). Pollen germination of Three Aquatic Plant Species. Adv Pollen Spore Res 29:107-117.

Bliskup A, Izmailow R (2004). Endosperm development in seed of Echium vulgare L. (Boraginaceae) from polluted sites. Acta Biol Cracoviensia Ser Bot 46:29-44.

Bilderback DE (1981). Impatiens pollen germination and tube growth as a bioassay for toxic substances. Environ Health Perspect 37:95-103.

Dafni A, Firmage D (2000). Pollen viability and longevity practical, ecological and evolutionary implications. Plant System Evol 222:113-132.

Dafni A, Pacni E, Nepi M (2005). Pollen and stigma biology 83 142 p. In: Dafni A, Kevan PG, Husband BC (Eds.). Practical Pollination Biology. Cambridge, Ontario, Enviroquest Ltd.

Dechamps C, Lefebvre C, Nort N, Meerts P (2007). Reaction norms of life history traits in response to zinc in Thlaspi caerulescens from metalliferous and non-metalliferous sites. New Phytol 173(1):191-198.

Deng J, Liao B, Ye M, Deng D, Lan CH, Shu W (2007). The effect of heavy metal pollution on genetic diversity in zinc/ cadmium hyper accumulator Sedum alfredii populations. Plant Soil 297(1-2):83-92.

Dickinson DB (1978). Influence of borate and pentaerythriol concentrations on germination and the tube growth of Lilium longiflurum pollen. J Am Soc Hortic Sci 103:413416.

Franklin FCH, Lawrence MJ, Franklin-Tong E (1995). Cell and molecular biology of self-incompatibility in flowering plants. Internat Rev Cytol 158:1-64.

Gauch Hg, Dugger WM Jr (1953). The role of boron in the translocation of sucrose. Plant Physiol 28:457-466.

Grace JB (1993). The adaptive significance of clonal reproduction in angiosperms. Aquatic Bot 44 (2-3):159-180.

Hasegawa Y, Nakamura S, Uheda E, Nakamura N (2000). Immunolocalization and possible roles of pectins during pollen growth and callose plug formation in angiosperms. Grana 39:46-55.

Heslop-Harrison J (1987). Pollen germination and pollen-tube growth. Internat Rev Cytol 107:1-78.

Izmailow R (2000). Reproduction of Viccia cracca L. in the 
polluted environment of the Legnica-Glogow copper basin (Poland). Acta Biol Cracoviensia Ser Bot 42(2):125-133.

Izmailow R, Bliskup A (2003). Reproduction of Echium vulgare L. (Boraginaceae) at contaminated sites. Acta Biol Cracoviensia Ser Bot 45(1):69-75.

Jassen AWB, Hermsen TGTH (1976). Estimating pollen fertility in Solanum species and haploids. Euphytica 25:577-586.

Johri BM, Vasil IK (1961). Physiology of pollen. Bot Rev 27(3):325-381.

Kelly JK, Rascha A, Kalisz S (2002). A method to estimate pollen viability from pollen size variation. Am J Bot 89(6):1021 1023.

Klein M (2000). Pollen studies in plant breeding and selection. Bot Guidebooks 24:171-193.

Kobayashi S, Hanada T, Nakamura N (2001). Callose plug formation and plug ingrowths in the pollen tubes grown in vitro. Jap J Palynol 47:13-20.

Koscinska-Pajak M (2000). Microspores and pollen grain in triploid Chondrilla juncea L. from unpolluted and polluted areas. Acta Biol Cracoviensia Ser Bot 42(2):135-140.

Laitiainen E, Nieminen KM, Vihinen H, Raudaskoski M (2002). Movement of generative cell and vegetative nucleus in tobacco pollen is dependent on microtubule cytoskeleton but independent of the synthesis of callose plugs. Sexual Plant Reprod 15:195-204.

Les DH, Philbrick CT (1993). Studies of hybridization and chromosome number variation in aquatic angiosperms: evolutionary implications. Aquatic Bot 44:181-228.

Malayeri BE, Chehregani A, Mohsenzade F, Golohammadi R (2005). Effect of heavy metals on the developmental stages of ovule and embryonic sac in Euphorbia cheiradenia. Pakistan J Biol Sci 8(4):622-625.

Malik CP (1977). Enzymes in pollen development and pollen tube growth. Adv Pollen Spore Res 2:58-65.

Mandal S, Barui NC, Ganguly PN (1982). In vitro studies on pollen germination in Arachis hypogeal L. Sci Cult 48:115116.

Micieta K, Murin G (1996). Microspore analysis for genotoxicity of a polluted environment. Environ Experim Bot 36(1):21 27.

Montaner C, Floris E, Alvarez JM (2003). Study of pollen cytology and evaluation of pollen viability in vivo and in vitro test, in borage (Borago officinalis L.). Grana 42:33-37.

Mulcahy DL (1975). The reproductive Biology of Eichhornia crassipes (Pontederiaceae). Bull Torrey Bot Club 102:18-21

Nyggard P (1977). Utilization of exogenous carbohydrate for tube growth and starch synthesis in pine pollen suspension culture. Physiol Plant 39:206-210.

Nyine M, Pillay M (2007). Banana nectar as a medium for testing pollen viability and germination in Musa. Afr J Biotechnol 6:1175-1180

Ostrolucka MG (1989). Differentiation of male reproductive organs and oak fertility in urban environment. Biologit 44(9):793-799.

Ostrolucka MG, Bolvansky M, Tokar F (1995). Vitality of pine pollen (Pinus sylvestris L. and Pinus nigra Arnold) on sites with different ecological conditions. Biologia 50:47-51.

Pal JK, Datta BK, Mandal S, Bhattacharya GN (1989). Studies on the in vitro pollen germination of Cassia fistulosa L. Mendel 6:3:126-128.

Parija P (1934). Physiological investigation on water hyacinth (Eichhornia crassipes) in Orissa with notes on some other aquatic weeds. Ind J Agric Sci 4:399-429.

Penfound WT, Earle TT (1948). The biology of water hyacinth (Eichhornia crassipes). Ecol Monographs 18:447-472.

Pfahler PL, Pereira MJ,Barnett RD (1997). Genetic variation for in vitro sesame pollen germination and tube growth. Theor Appl Genetics 95:1218-1222.

Picton JM, Steer MW (1982). A model for mechanism of the extension in pollen tubes. J Theor Biol 98:15-20.

Ramanna MS (1975). Pollen tube growth in Spinacea oleracea L. Euphytica 24(2):337-340.

Sari-Gorla M, Frova C (1997). Pollen tube growth and pollen selection, 323-351 p. In: Sawhney and Shivanna (Eds.). Biotechnology and Crop Improvement.

Shivanna KR, Johri BM (1985). The angiosperm pollen structure and function. Wiley Eastern Ltd. Publisher, New Delhi

Shivanna KR, Johri BM (1989). The Angiosperm pollen structure and function. Wiley Eastern Ltd, New Delhi.

Singh A, Paolillo DJ (1990). Role of calcium in the callose response of self-pollinated Brassica stigma. Am J Bot 77:128 133.

Stace CA (1991). Plant Taxonomy and Biosystematics. $2^{\text {nd }}$ Ed. Cambridge University Press, Cambridge.

Stanely RG, Linskens HF (1964). Pollen biology, biochemistry and management. Springer, Verlag. Berlin, Heidelberg, New York, 21-27 p.

Sulaman W, Arnold M, Yu K, Tulsieram L, Rothstein SJ, Goring DR (1997). Loss of callose in the stigma papillae does not affect the Brassica self-incompatibility phenotype. Planta 203:327-331.

Vishnyakova MA (1991). Callose as an indicator of sterile ovules. Phytomorphology 41:245-252.

Wang Q, Lingan K, Huaiqing H, Xiaohua W, Jinxing L, Jozef S, Frantisek B (2005). Effects of brefeldin s on pollen germination and tube growth. Antagonistic effects on endocytosis and secretion. Plant Physiol 139(4):1692-1703. 